\title{
The Appraisal Problems of Misjudged Criminal Cases - An Empirical Research Based on 50 Cases
}

\author{
Lang Zhicheng \\ Criminal Investigation Department, Southwest University of Political Science and Law, Chongqing, China \\ Email address: \\ 857656094@qq.com \\ To cite this article: \\ Lang Zhicheng. The Appraisal Problems of Misjudged Criminal Cases - An Empirical Research Based on 50 Cases. International Journal of \\ Law and Society. Vol. 1, No. 3, 2018, pp. 125-136. doi: 10.11648/j.ijls.20180103.15
}

Received: June 18, 2018; Accepted: October 18, 2018; Published: December 4, 2018

\begin{abstract}
The reason why the misjudged criminal cases exist is not due to the application of law, but due to the deviation of fact-foundings, which are the errors in appraisal. Based on the empirical study, this research uses the inductive and deductive methods to analyse the appraisal problems in misjudged criminal cases of China and study the main reasons that cause the misjudged criminal cases. The reasons includethe pressure that urges the investigative organs to solve the cases, the quality and the quantities of the evidence the professional abilities of the appraisers, the reliability of the investigative technology, the problems in the exploration, examination and extraction the evidence and in reconstruction the criminal scenes, and the deliberate wrong appraisal etc.. The solution, first of all, is to reform the appraisal system to keep it neutral. Firstly, the internal appraisers of investigation organs should be separated from the investigation organs. Secondly, the rights of the relevant parties should be protected to restrict powers with rights. Meanwhile, the investigation organs should establish an appraisal recordation system. And finally, the interest parties should be allowed to participate in the appraisal process and strengthen the supervision over appraisal activities and summary of past facts.
\end{abstract}

Keywords: Misjudged Criminal Cases, Problems in Appraisal Empirical Research, Reform Measures

\section{Introduction}

The appraisal opinions are the professional opinions that are identified, judged and then given by the appraisers according to their professional knowledge as well as the scientific technologies in the criminal proceedings. The correctness of the appraisal opinions will influence the procedural justice and even the entity justice. The problems produced in the judicial identification are closely related with the basic rights of the relevant parties. Due tothe intelligent and technical of the modern criminal activities, the judicial appraisal activities play an important role in finding, and confirming fighting criminal activities in the Public Security Bureau's criminal procedural inspection. The appraisal opinions are also frequently regarded as the foundation to decide on a verdict in ascertaining the facts of cases. There are three functions: first of all, the appraisal opinions are the foundation to file the report. For example, the ingredient and quantity of the drug are the key factor for investigation organs to decide whether it reaches the limit to fill a criminal case. Moreover, the appraisal opinions, given by medical examiners of the cause of death, whether a person commits suicide or is murdered, are also the cores for investigation organs to decide if it should be filed a case or not. Secondly, the appraisal opinions provide the inspection activities with essential clues for detection. In the cases of traditional violent crimes like rape-murder androbberies, the appraisal opinions on the bloodstain, the hair andthe semen etc. are the important ground for the investigation organs to search the criminal suspect. The DNA identification also helps to determine the investigative direction, locate the suspects and greatly reduce the cost of investigation. What's more, the appraisal opinions regarded as litigation evidence can prove the criminal facts andcan also be references to measure the conviction and sentencing. Therefore, appraisal opinions are vital to criminal justice.

However, the appraisal opinions aren't always reliable. The public security organs, procuratorial organs and people's courts can be overly dependant on it or exaggerate their probative value, which results in other problems. In recent years, the problems existing in appraisal have been explored gradually, especially in the field of the misjudged criminal cases. Therefore, it's necessary for a research about the 
appraisal problems in the misjudged criminal cases. As a french scholar Rene Floriot said that "There is no doubt that once the identification is wrong, the judgement will deviate from the fact." [1] In China, the appraisers usually won't appear on the court and be subject to the cross-examinations due to their special identification. However, the appraisal opinions usually play the role of "scientific judge" in the judicial proceedings, which leads to that these wrong appraisal opinions become the basis of judges ascertaining the facts. In practice, the wrong appraisal opinions are the chief culprit in many misjudged cases. [2]

So far there are many researches about the misjudged cases. There is no doubt that the reflection of the misjudged cases and wrong appraisal opinions produces positive influences and have already made some achievements. For example, professor Guo figured out that it is not reasonable to set identification institution inside the investigation organs according to the wrong appraisal opinions in 13 misjudged cases. It figured out that investigation should be separated from the identification system, establish the model of compulsory forensic appraisal of related - dead-cause cases, and preserve the appraisal material to make sure the interest parties can apply re-identification etc.. Professor Chen empirically analyzed 20 misjudged cases. Studied the accusation of the defendant, the social bracket, the participant of attorney, the administrative regions and the correction reasons. Could got a conclusion that themisjudged cases were caused by the overly dependant on the testimony, the ignorance of the appraisal technology, and the negligence of the forged evidence and the evidence of innocence. Besides, also offered suggestions to reform the system. In addition, there are also some other scholars to reflect the appraisal problems in the misjudged and misjudge cases. However, the writer think that this kind of reflection is not clear and thorough enough. First of all, for people's court and the procuratorate, they mainly consider the problems that occur to the organs or officials at organs in dealing with the cases. They seldom pay attention toor even neglect the appraisal opinions that may cause the misjudged criminal cases. Moreover, although some scholars have studied the appraisal opinions that may cause the misjudged criminal cases, [3] or have carried out empirical researches over a series of cases, the types of cases may be not comprehensive or may be far from now, most of which happened in the $90 \mathrm{~s} 20^{\text {th }}$ [4], so the latest cases like "Uncle and Nephew ZHANG" did not be included in their researches. Finally, there aren't many studies about the cause nor the basic regulars of the appraisal opinions that may cause the misjudged criminal cases, as well as the suggestions to complete the reform, therefore this topic needs further investigation.

\section{Analysis of the Misjudged Cases and the Appraisal Problems}

Taking 50 unjust verdicts that caused a stir in China in recent ten years as research samples, the writer will study the misjudged criminal cases, the types of appraisal problems, the forming reasons, and the solving methods ${ }^{1}$. Due to the objective factors, the quantity and the standard deviation may be not reasonable, and meanwhile some cases are far from the actual time, so that they may not provide strong reference. However, they can still reflect the typical appraisal problems.

\subsection{The Basic Characters of Misjudged Criminal Cases}

\subsubsection{Criminal Types and Appraisal}

Among the 50 misjudged cases listed in chapter 1, the criminal types are variedsuch as intentional murder, intentional injury, rape and robbery etc.. These criminal cases are mostly violent crimes that interfered murder. They usually have negative social effects, complicated details and wide attention from society.

In these cases, there are 38 intentional murder cases, 13 rape cases, 9 robbery cases and 7 rape with intentional murder cases, which takes $76,26,18$ and $14 \%$ respectively. These presented cases all comform to the eight serious criminal types: the intentional murder, the intentional injury to death, explosion, poisoning, marson, robbery, rape and kidnapping, which are the socalled homicide cases. Meanwhile, these cases all concern the judicial appraisal in the criminal proceeding but it may be influenced by the samples that the writer chose which don't have the popularity.

The domestic scholars have studied some criminal types and appraisal problems in chapter 1. For example, a scholar has studied a statistics over 137 misjudged cases and found out that there existed different degrees of forged appraisal opinions. Among the 13 misjudged cases, 9 of them weremisjudged intentional injury cases, 3 of them were misjudged intentional murder cases and one was misjudged rape case." [5]

\subsubsection{The Administrative Regions and Appraisal}

From the view of geographical distribution, among the 50 misjudged cases, 4 cases happened in east China (Zhejiang Province, Fujian Province and Shandong Province), 7 misjudged cases in northeast province, 30 misjudged cases in the central China (11 misjudged cases in Henan Province, 8 misjudged cases in Hebei Province), and 8 misjudged cases in west China (4 cases respectively in Yunan Province and Guangxi Province). Sixty percent of the misjudged cases happened in central China (22\% in Henan Province and 16\% in Hebei Province), $14 \%$ in northeast China and 16\% in west area.

The misguided criminal cases mostly happen in west and central areas. It's related to the local economic development, judicial officials' professional skills, the local judicial tradition and the judicial criminal appraisal. The reliability of judicial appraisal opinions are also concerned with the abilities of the local technician, devices and equipment etc. However these regions are less developed and lack experts in judicial appraisal, so that they failed to reach the appraisal standard. For example, most cases need DNA identification. However,

1 Standard Deviation is also called the mean square error. It's the average number of the interval that all numbers deviates from the the average..............the Standard Deviation reflects the distribution of the data. The average is the same doesn't mean the standard deviation is the same. 
the accuracy and popularity of DNA identification in central and west provinces weren't as good as the other provinces in the $1990 \mathrm{~s}$ and the early $21^{\text {st }}$ century. Therefore, the cases, which weren't identified by the DNA identification, were overly dependant on the witness and thus resulted in the misjudged cases.

Table 1. A Statistical Table of 50 Unjust Cases.

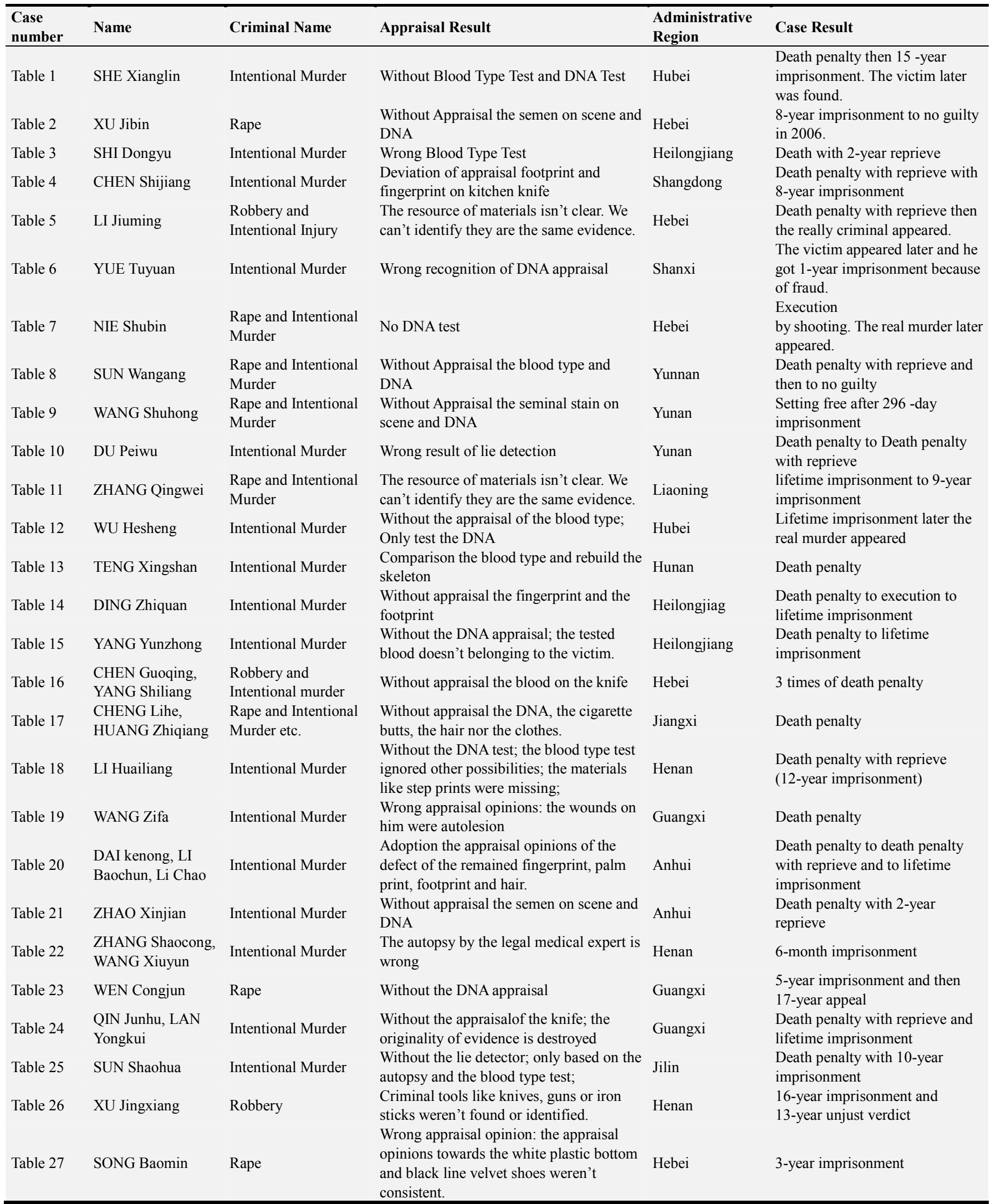




\begin{tabular}{|c|c|c|c|c|c|}
\hline $\begin{array}{l}\text { Case } \\
\text { number }\end{array}$ & Name & Criminal Name & Appraisal Result & $\begin{array}{l}\text { Administrative } \\
\text { Region }\end{array}$ & Case Result \\
\hline Table 28 & XU Dongchen & Intentional Murder & $\begin{array}{l}\text { The appraisal opinions aren't unique or } \\
\text { exclusive. }\end{array}$ & Hebei & $\begin{array}{l}4 \text { times death penalty, } 8 \text {-year } \\
\text { imprisonment and } 8 \text { times on } \\
\text { trials }\end{array}$ \\
\hline Table 29 & LIU Qian & Rape & Without the blood type test & Hebei & 6-year imprisonment \\
\hline Table 30 & ZHANG Congming & $\begin{array}{l}\text { Robbery and } \\
\text { Intentional murder }\end{array}$ & Without the DNA test & Henan & Death penalty \\
\hline Table 31 & MENG Cunming & Rape & Without the semen stain appraisal & Hebei & 9-year imprisonment \\
\hline Table 32 & HE Jinan & Intentional Murder & $\begin{array}{l}\text { Without the blood stain appraisal nor } \\
\text { investigation the source of the blood }\end{array}$ & Shanxi & Death penalty \\
\hline Table 33 & WANG Junchao & Rape & $\begin{array}{l}\text { Without the DNA appraisal; carelessness } \\
\text { in blood type test. }\end{array}$ & Henan & $\begin{array}{l}\text { 9-year imprisonment then the } \\
\text { really murder appeared }\end{array}$ \\
\hline Table 34 & $\begin{array}{l}\text { LU } \\
\text { Rong xin }\end{array}$ & $\begin{array}{l}\text { Murder } \\
\text { Rape }\end{array}$ & $\begin{array}{l}\text { The extraction and identification of DNA } \\
\text { materials do not meet the requirements of } \\
\text { legal procedures }\end{array}$ & Yunnan & Death penalty \\
\hline Table 35 & QIN Yanhong & Rape & Without the appraisal of semen nor DNA & Henan & $\begin{array}{l}\text { 4-year imprisonment then the } \\
\text { really murder appeared }\end{array}$ \\
\hline Table 36 & WANG Haijun & Intentional Murder & $\begin{array}{l}\text { Only the blood type test; without the DNA } \\
\text { test; }\end{array}$ & Jilin & $\begin{array}{l}15 \text {-year imprisonment then the } \\
\text { really murder appeared }\end{array}$ \\
\hline Table 37 & WANG Junchao & Rape & $\begin{array}{l}\text { Without the DNA appraisal; carelessness } \\
\text { in blood type test. }\end{array}$ & Henan & 6-year imprisonment \\
\hline Table 38 & ZHANG Shaoyou & $\begin{array}{l}\text { Rape and Intentional } \\
\text { Murder }\end{array}$ & Without the appraisal of seminal DNA & Henan & Death penalty \\
\hline Table 39 & $\begin{array}{l}\text { Fan Jiali, FAN } \\
\text { Rongsuo }\end{array}$ & Intentional Murder & Without the appraisal of blood DNA & Yunan & Death penalty \\
\hline Table 40 & SHI Yansheng & Intentional Murder & $\begin{array}{l}\text { Inconsistence between samples and } \\
\text { materials of footprint and fingerprint }\end{array}$ & Heilongjiang & Death penalty with reprieve \\
\hline Table 41 & LI Zhiping & Intentional Murder & $\begin{array}{l}\text { Without correct appraisal of blood type } \\
\text { noe palm print }\end{array}$ & Hebei & Death penalty with reprieve \\
\hline Table 42 & $\begin{array}{l}\text { CHEN Yang, TIAN } \\
\text { Weiping }\end{array}$ & Robbery and Burglary & Lack of the fingerprint appraisal & Zhejiang & Death penalty with reprieve \\
\hline Table 43 & $\begin{array}{l}\text { ZHANG Gaoping, } \\
\text { ZHANG Hui }\end{array}$ & Rape and murder & $\begin{array}{l}\text { Without the semen; without the appraisal } \\
\text { of the male DNA remained in the finger }\end{array}$ & Zhejiang & $\begin{array}{l}\text { Death penalty with reprieve and } \\
15 \text {-year imprisonment }\end{array}$ \\
\hline Table 44 & GAO Qinghong & Intentional Murder & Forged footprints & Henan & Death penalty with reprieve \\
\hline Table 45 & $\begin{array}{l}\text { QIN Junhu, LAN } \\
\text { Yongkui }\end{array}$ & $\begin{array}{l}\text { Robbery and } \\
\text { Intentional murder }\end{array}$ & $\begin{array}{l}\text { Without the appraisal of the evidence } \\
\text { (knife) }\end{array}$ & Guangxi & $\begin{array}{l}\text { Death penalty with reprieve and } \\
\text { lifetime imprisonment } \\
\text { respectively }\end{array}$ \\
\hline Table 46 & YANG Botao & $\begin{array}{l}\text { Rape and Intentional } \\
\text { Murder }\end{array}$ & $\begin{array}{l}\text { Without the appraisal of fingerprint nor the } \\
\text { excrement }\end{array}$ & Henan & $\begin{array}{l}\text { Death penalty with } 10 \text {-year } \\
\text { innocent imprisonment }\end{array}$ \\
\hline Table 47 & WANG Benyu & $\begin{array}{l}\text { Rape and Intentional } \\
\text { Murder }\end{array}$ & $\begin{array}{l}\text { Extorting confessions by torturing; } \\
\text { without appraisal the victim; }\end{array}$ & Neimenggu & $\begin{array}{l}\text { Death penalty with reprieve, } \\
18 \text {-year in prison }\end{array}$ \\
\hline Table 48 & NIAN Bin & $\begin{array}{l}\text { Throwing Hazardous } \\
\text { substance }\end{array}$ & Doubts remain in appraisal opinions & Fujian & Death penalty \\
\hline Table 49 & Hugejiletu & $\begin{array}{l}\text { Intentional murder } \\
\text { and hooliganism }\end{array}$ & $\begin{array}{l}\text { Without the appraisal of excreta DNA; } \\
\text { Only test the blood; }\end{array}$ & Neimenggu & Death penalty \\
\hline Table 50 & YU Yingsheng & Intentional Murder & $\begin{array}{l}\text { Ignorace of the appraisal opinions of } \\
\text { fingerprint and semen stain }\end{array}$ & Anhui & $\begin{array}{l}\text { Death penalty to death } \\
\text { penaltywith reprieve and to } \\
\text { lifetime imprisonment }\end{array}$ \\
\hline
\end{tabular}

\subsection{The Appraisal Problems in Misjudged Criminal Cases}

Although the listed 50 cases are different in details, the problems share the same character. ${ }^{2}$

2 The Judicial Appraisal can be sorted as Evidence Identification Science, Medicolegal Expertise, Forensic Psychiatric Expertise, Forensic Accounting Appraisal according to the subjects and according to the objects and content can be sorted as the Survey and the Appraisal of the Corpse, the Injury Appraisal, Mental the Disease Appraisal, Medical Accident Appraisal, the Trace Appraisal, the Paper Appraisa, Microcontent Identification, Video(electronic) Evidence Appraisal, Accounting Proof Appraisal, Construction Program and the Product Appraisal and the other appraisals. For more details readers can refer HE Jiajong. The Introduction to Judicial Appraisal [M]. Beijing: Law Publishing House, 2000.75-83.

\subsubsection{Without Appraisal}

Among the 50 cases, there are 28 cases without appraisal which were supposed to be appraised. They are mostly international murder and rape without the appraisal of semen and blood types. For example, in the $\mathrm{Hu}$ ge ji le tu case, the officials took the test of blood types as the irrefutable evidence and ignored the DNA appraisal towards vaginal secretions. If the officials appraised the DNA, this misjudged case can be eliminated. Meanwhile, in the 1990s, after the Xu Xianglin case explored to public, people had doubts in whether the nameless female corpse is the wife named ZHANG Zaiyu. The officials only needed to exam the DNA but they overly depended on the recognition of Zhang Zaiyu's relatives to target the suspect. 
It realize that the misjudged cases happened frequently due to the lack of appraisal equipment in that region. In 1984 of UK, the geneticist Alec Jeffreys discovered the Desoxyribonucleic Acid Identification, and in 1988 of UK the murder suspect Colin Pitchfork was the first person to be arrested by means of DNA identification. However, in China, the application of DNA identification was later and the applicable fields were also limited. Research shows that until 2009 , less than $2 \%$ DNA identification was used in criminal cases, and meanwhile even less than 10\% DNA identification was applied in murder and rape cases. [6] There are many misjudged cases happened even earlier in the 1990s, such as the $\mathrm{Xu}$ Xianglin case. At that time we only have very countable DNA identification organizations. This is the result of the limited appraisal technology.

Suganjiali, the first case in the world caused by DNA tests, was released in early June after confirming that the fluid in a girl's underwear did not match the suspect's DNA. The criminal case was actually caused by a false comparison of evidence. Legally speaking, the error of evidence comparison mainly refers to the error of blood, fingerprint, semen, saliva, sweat stain, blood protein, blood type and other related physical evidence in the process of comparison.

In foreign countries, the error of evidence comparison is an important factor leading to criminal error. Although DNA certification technology has been widely used in criminal investigation procedure, but there still exists certain error rate of DNA technology itself. The immature of the DNA identification technology is the major causes of criminal misjudged cases.

\subsubsection{The Unclear or Polluted Original Evidence Without Consistency}

In the appraisal, the comparison of original evidence and the samples are extremely important. Once the original materials are polluted, it will lose its quality to be appraised. Even if it is used to be appraised, the characters aren't consistent. In the listed 50 cases, apart from the two cases that can't be found, the inconsistent comparative appraisal is 4 cases $(8 \%)$. For example, in the Zhang Qingwei case, the source of the blood isn't clear, and meanwhile the function of the blood test is only can be used to eliminate. In this case, it did not have the DNA identification (the consistency identification). In Shi Yansheng's case, the appraisal samples of the footprints and fingerprints did not have the consistency. However, the appraisers still thoughtthat the original materials were consistent which resulted in the misjudged case.

The original materials are mainly from the investigation on scene. The investigators will block the scene once they receive the report. They investigate, extract and preserve the materials on the scene. If they can extract the effective evidence, preserve the evidence according to the procedure and exam the evidence scientifically, wrong appraisals can be avoided. However, in judicial practice, because of the following reasons, it's hard to extract and presearve the evidence accurately.

(1) The limited investigation ability. The presented misjudged cases mainly happened in rural areas where the economy wasless developed and the transportation was inconvenient. Even if the police received the report the first time, they could not arrive at the scene immediately. "The first several hours after the case happened are very important for investigation. Failing to use the limited golden time means increasing the possibility of misjudged cases. "The quantity of the police in China is nearly 2,000,000, which is far less compared with developed countries."[7] China is in great short of the police force. The police need to deal with too many cases everyday. These are also the reasons resulting in the problems of the extraction of evidence.

(2) The limitation of investigation technology. The extracted evidence need preservation which willneed expense. The listed cases mostly happened in the central and west regions, and they usually have limited budget for solving the cases. According to the principles of preserving evidence, the hair need to be separated, and the complicated, fragile and perishable evidence need higher preservation standard. The semen and the blood stain extracted from the scene can be easily polluted or destroyed, which willresult in unidentified materials or wrong appraisal results. For example, in Qin Junhu and Lan Yongkui's case, the size of their shoes is $24 \mathrm{~cm}$, while the size that the policed founded on scene is $27.2 \mathrm{~cm}$. Even though they are different, the investigator regarded the two different sizes as the same evidence. In the end the shoes were somehow missing. Imaging that if the evidence of the shoes were well kept, they can be powerful evidence to prove them innocent if they get the chance of retrial. In Chen Shijiang's case, the police found a knife with the blood of victim and possibly the fingerprints of the murder, however they didn't extract the fingerprints on the knife. When the poof need to be presented, the fingerprints on the knife disappeared because of poor kept condition. Therefore, the police could not comfirm who used this knife to kill the victim. [7]

(3) Careless investigation on scene. The analysis isn't thorough. The investigation isn't comprehensive. The disposition isn't properly together with low positiveness and carefulness from the police. They are overly dependant on the traditional investigation method and ignorant of the micro materials like the e-date. In Zhao Zuohai's case, the police didn't carry on further investigation after they found the headless corpse. Until the time that the case was rehabilitated, the police found three stones which was placed on the corpse, and rotted head and two arms belonging to the headless corpse. Lack of DNA appraisal is one of the reasons for misjudged cases, however if the investigation on scene and cross-examination is carefully enough, it will be easy to exclude the suspect and avoid the misjudged cases. 


\subsubsection{The Faults of Appraisers and the Forged Appraisal}

In the appraisal, the carelessness of judicial appraisers can also result in wrong appraisal opinions. For example, some scholars have stated that the dereliction of duty of experts to some degree has threaten the justice of judicial system. For example, in Yue Tuyuan's case, the wrong appraisal explanation of DNA identification led to this misjudged cases. In Li Huawei's case, the investigation organs revised the appraisal opinions arbitrarily and changed the investigation direction to preserved direction. In a typical case of Du peiwu, the investigation organs made a lot of efforts and used the lie detector. No matter what the conclusion is, Du Peiwu killed the person or he was lying.

The writer investigated Kuming criminal the first trial No.394 "Criminal Judgement" of the intermediate people's court in Kunming city (1998), and found the related appraisal: (1) According to the examination, the police shirt wore by the defendant Du Peiwu was detected and the attached powder material of the shooting of military gun was found on his right sleeve. Therefore the defendant Du Peiwu was identified as shooting with military gun in this shirt. (2) The smell of the sand retained on the clutch and pedals of the driving seat of the car (YUN OA0455, minivan, brand: CHANGPING) were compared with that of the socks of DU Peiwu. The trained police dog found that they belong to the same smell, therefore DU Peiwu had drove the car (many times of test). However, the investigation notebook and the photograph on scene recorded that the clutch of the car remained the sand, while later in the notebook this record didn't exist any more. And the appraisal resulted from the identification of the dog shouldn't be regarded as the evidence to judge DU Peiwu.

If the DU Peiwu's cases isn't powerful enough to reflect the problem, the case of the ZHANG Uncle and Nephew can also help to prove. In this case, the appraisers extracted the DNA from the eight fingers of the victim. The appraisal result is that the DNA belongs to the victim and another man. Therefore the organs excluded the criminal possibilities of the ZHANG. However the judgement of Hangzhou intermediate people's court held the opinion that the DNA remained on the end of the fingers of the victim can't exclude the possibility that it was originated from the daily affairs because hands aren't somewhere private. Zhejiang Province Supreme Court held the opinion that the DNA appraisal had no connection with this criminal case. This judgement denied the connection of the appraisal opinion with the case and resulted in this misjudged case. Finally the police found out that the DNA belonged to the real murder in the later correction.

The same situation for XU Dongchen's case, the main opinion was that the possibility that the DNA remained in the tissue used to eraser the semen on SHA's vagina belonging to the suspect XU Dongchen can not be excluded. [8] Also in YUE Tuyuan's case, the wrong explanation of appraisal results made deviation from the fact.

\subsubsection{Improper Usage of Appraisal Opinion}

As a professional guidance to confirm the evidence, appraisal opinions need to be used properly. For example, in
HUGEJILETU's case, the investigation organ target the suspect only according to the blood type test. As a matter of fact, this appraisal result should only be used to exclude the suspect. The improper use of the appraisal resulted in the misjudged case directly. In the similar 28 cases without DNA identification, they merely took the test of blood type. The functions of the blood type test are doubtless. However it's not powerful enough to target the suspect. In these cases the investigation organs misused the appraisal opinions to judge the wrong suspects.

Another presence of improper usage of appraisal opinions is overly dependant on appraisal opinions. Among all kinds of evidence, the appraisal opinions are just one of them. Thinking too highly or ignoring it will lead to misjudged cases without doubt.

\subsection{The Functions of the Appraisal in the Misjudged Cases}

Judicial appraisal opinion is an important part of the evidence system, and it is the key to the whole appraisal system. Problems in appraisal opinions can cause countless effects to misjudged cases. The performance are as follows:

(1) Wrong appraisal opinions will lead to wrong investigation direction, resulting in missing the best time to investigate. For example, in DU Peiwu's case, the fault of the police dogs' smell, the lying detector, the wrong appraisals of the pedal with sand and the shirt with blood mislead the target to DU Peiwu and make people believe that he was the murder. After many times of countless questioning and torture, they finally made DU Peiwu committed murder.

(2) Investigators regards the appraisal opinions as the Bible and ignore the common sense.

(3) Replacing the judgement with the appraisal. The subjective and objective matters in appraisal will influence the reliability of the appraisal opinions. For judicial practice, due to that the judges don't have professional knowledge of the appraisal, they don't have the judgement about the appraisal results, which can lead to wrong judgement about the evidence and result in misjudged cases. In this process, the appraisal result plays the role of the trial result. We can see that it is lethal to replace the judgement with appraisal opinions.

The proper and reasonable usage of the appraisal opinions is vital. However in the suing and trial, the judicial organs possess weak judgement about appraisal results, which can lead to misjudged cases. For example, in NIAN Bin's and ZHAO Zuohai's case the ignorant of the DNA identification led to the misjudged cases.

\section{The Reasons of Appraisal Problems in Criminal Misjudged Cases}

No matter how perfect the legal system of a country, if the problems can't be discovered or revised in time, the bug will expand to a degree that is hard to cover. When the bug become more serious, it will not take the responsibility to rule the 
society, and new problems will arise. In the proceeding process, due to people's limitation of learning and the lack of actual evidence, there is no way to avoid misjudged cases. [9] However, to make people feel justice in every case asks people to strictly obey the judicial line. [10] In recent years, the cases revealed by the media have shown high frequency of criminal misjudged cases ${ }^{3,}$ such as NIE Shubin's case, SHE Xianglin's case, ZHAO Zuohai's case, NIAN Bin's case and XU Hui's case $^{4}$, which all have appraisal problems. Therefore, the writer holds the opinions that people need to know the reasons of appraisal problems.

First of all, it's the pressure of solving cases. At the transformation of society, the police face a lot of pressure. The statistics show that, from 1990, 6819 members of police died in the line of duty ( 1.2 person per day) and 120783 members were injured (20.7 per day). [11] From 2006 to 2011, 1029 police died of overload which took $47 \%$ of the sacrificed police. From the May of 2010, 2167 policemen died in the line of duty and 17988 policemen were wounded (about 400 policemen died and 3000 policemen wounded per year). Overload to death has become the main reason for police to die. Most of the time when the misjudged cases happen, people will seldom think of the burden of the police but to blame them. For example, in a questionnaire about Beijing Policemen' Resource of Stress, the working style, personal ability, interpersonal relationship, leadership and stress adds up to $3.2+0.8$. [12] For the developed Zhejiang Province, more than 400,000 criminal cases occur every year. Most of the police need to do extra work and work out side of the schedule. Their physics and psychology have certain problems Thinking of murder to be solved and the demanded number of case task, they urge themselves to make break through, which willresult in carelessness in details.

Secondly, it's the quality and quantity of evidence. The quality and quantities of the evidence can influence the appraisal result to a certain extent. For example, the appraisal results can be influenced by the clarity of the evidence, the matching-degree of the main characteristics and whether the fingers are injured. For the quality of the proof, clear, reliable and sufficient evidence can reach the fact. However, incomplete or unclear proof will deviate from the fact.

Taking the polluted or improper preservation of the DNA for example, in the process of extraction and preservation, to keep it in good condition, the following steps should be carried out carefully: (1) The investigators should make the scene not to be changed; (2) Before transferred, the investigators should avoid the crossing-pollution among

3 Reader can refer the $<<$ the Party's Decision about Several Problems to the Deeper Revolution to All Aspects $>>$ passed by the third plenary session of the Party.

4 XU Xianghui was accused rape in the August 1998, and killed his female young neighbor Yan. In May 2001, the intermediate court in Zhuhai judged him murder and rape and sentenced him to death with a two-year reprieve and abolished his political rights in the first trial. After long appealing, in the $15^{\text {th }}$, Sept. 2014, this court announced him innocent. The write didn't list the analysis because of the limitation to the pages of the passages. Details can be viewed in Chinese Misjudged Cases Net. proofs and materials

Thirdly, the skills of the appraisers are important. In the appraisal fields, the professional skills, experience and professional morality are variable, and the appraisal opinions are different. The appraisal opinions are influenced by the professional abilities of the appraisers. For instance, the experienced appraisers may hold different opinions with the freshmen. That's why many judges take the experienced appraisers' opinions to judge cases.

Fourthly, the reliability of the criminal technology is also important. Generally speaking, the appraisal conclusion itself is obtained by scientific method instead of science itself. In the criminal proceeding appraisal, science is just a method instead of the science itself. Even for the DNA identification, there isn't much doubt on DNA identification theoretically, but the reasoning process, the accuracy of extraction material, the clarity, experimental condition and process are still uncertain. [13] In short, the reliability can be limited by the following factors.

Personnel: The appraisal was made by experts. The qualification and experience morality of the appraisers will directly influence the results. Therefore the subject factors influence the correctness of the appraisal result.

Material: The complicity of the extracted materials and the advanced degree of the appraisal tools consist of the physical basis for appraisal opinions. Lacking this guarantee to the materials, people can never reach the truth. Once the material evidence is incomplete or polluted, it will result inwrong appraisal opinions.

The process of appraisal: As the bridge between the appraisers and the investigation target, the process of appraisal is definitely important. Even for an experienced appraiser with advanced technology, the ways of preserving the materials, the time, the temperature, the moist and the process of reasoning can influence the conclusions to make sure the effectiveness of the result. Therefore, the reliability of criminal technology should be concerned with the person, materials and the appraisal process.

Extraction materials and reconstruction of the accidental scene are also the factors. Generally speaking, criminal suspects will destroy the scene and the evidence. From the time when the criminal happened to the time when the police received the report, the interval is sometimes even long to several years that it will be hard for the evidence to be extracted, such as the rotted corpses and the air-slake. For example, in the rape and murder case, once the scene is polluted, it will be hard to recognize the character of the case, the ways of crime, the trace and fingerprints. The scurf and hair falling from the investigators can all pollute the DNA.

Intensive misjudgment: For the maintenance judicial appraisal system, there are still someone who gives intensive appraisal judgment to get benefits and thus result in misjudged cases. The forged appraisals aren't rare cases. For example, in XU Dongchen's case, the investigators only test the blood of four suspects (XU Dongchen included) without further test to make sure that XU Dongchen's test are consistent with the semen remained on the vagina of the victim. It is ridiculous 
that the police judge him guilty by this appraisal, and when his family argued for retrial, the tissues and evidence were missing. Obviously it's a wrong appraisal.

Another example, in LI Jiuming's case, the police took the hair, the blood, the DNA test, footprint appraisal, smell appraisal and the lie detectors. However, when the police sent the materials to the investigation, they didn't clarify when the hair or blood was extracted, when it was sent to the police and who sent it to the police. They arbitrarily believed that the blonde size 40 shoes belonged to LI Jiuming. The bug is so obvious but no one was aware of it. Finally it caused the misjudged case.

To draw a conclusion, the wrong appraisal was mainly caused by the following factors: (1) the intentional forged facts; (2) the limited professional abilities and lack of work responsibilities; (3) improper use of the appraisal opinions; (4) the improper ways to collect the materials. [14]

\section{The Exploration to Complete the System}

Based on the criminal misjudged problems, the writer holds the opinion that the revolution should start from the appraisal system, appraisal procedure and the investigation on scene.

\subsection{The Criminal Proceeding Judicial Appraisal System}

According to the No.7 term of the National People's Congress of 2005 "the Decision about the Management of the Judicial Appraisal" (the writer simplified it as "Decision"), investigation organs can set up appraisal organs if needed. The investigation organs are the prosecution organs and the appraisers are the prosecutors. The appraisers of investigation organs will be influenced by the thoughts of guilty inference, which disobey the neutral position and result in the remaining problems. This phenomenon not only occurs in China, and even in British the expert witness the system suffering the same situation. Because the experiment is covered in the high pressure of assisting solving the case, the British government is also keen to trust the investigation organs. [15] In the investigation system of our country, allowing the investigation organs to set up appraisal organs will influence the judicial justice. Once the appraisal is wrong, it will severely damage the justice, like DU Peiwu's, YUE Tuyuan's, LI Zhiping's, and YU Yingsheng's case etc. As a conclusion, it's necessary to reform the appraisal system.

\subsubsection{The Neutrality of Revolution Appraisal System}

The speciality of investigation activities is closely concerned with the judicial appraisal activities. Because the appraisal organs are attached to the investigation organs and the prosecution character, the appraisal is hard to keep its neutrality. In investigation, it's necessary to appraise to prove the needed evidence but also to exclude and direct the investigation scope. It can also provide evidence support in closing the files, and transferring the proceeding process. But it has certain effects that the appraisal organs are attached to the investigation organs.

(1) The confusion of entity justice caused by investigation and appraisal. The investigators will go to the criminal scenes to collect the materials. This way of activities are effective but not always suit the justice. In practice, the appraisers have known the cases and formed their own judgement, which will subjectively influence the appraisal result. Therefore, if the appraisal organs don't depend on the investigation organs, the appraisers are hard to keep their neutrality and they will give wrong appraisal opinions for work pressure.

(2) The mixture of double identification (the investigator and the appraiser) can influence the procedure justice. According to the Criminal Law, the investigator (the prosecutor) and the other party (the appraiser) represent for different litigation parties and have different duties. However, the mixture of the two roles makes the goal of appraisal organs inclined to solve the case. If the appraisers follow the thoughts of investigators, they will put the focus on the direction suggested by appraisal and deviate from the neutrality. [16]

To know the truth of investigation and appraisal is to make better measures to reduce the side effects. Although "the Decision" reserves the system to set appraisal organs inside the investigation, we should also complete the related system and make sure the reliability and the neutrality by renew related system and procedures. The related measures are as follows.

Above all, the investigation organs should be separated from the appraisal organs. The appraisal organs and the investigation organs can be parallel organs, due to that the appraisal organs are technical organs designed to provide needed professional opinions. The third articles of "the Decision" regulates that the appraisal organs should register in the administrative department instead of attached to the investigation organs.

The second is realizing using rights to limit power. According to the $146^{\text {th }}$ article of Criminal Law, the appraisal opinions that are going to be used in trial should be informed to the suspects and the victim. If the suspects and the victims have requirement, there should be addicted appraisal and reappraisal. Although the law demands the duty to inform the suspects and the victims, it doesn't clarify how, when and the results. Therefore, proper revolution should be made to protect the questioning rights of suspects and victims. The informed content should not only conclude the transferring condition, preservation situation, appraisal procedure, measures and appraisal opinions, but also the basic introduction concludes both the conclusion and process, the delivery of the copy, the legal result and the relief procedures. The investigation organs should be responsible for the investigators' behavior that didn't inform the interests parties in written papers or the investigation exists defaults.

Meanwhile, the investigation organs should set up the record of examination of the materials, videos for checking and appraisal for further reappraisal according to the laws, which demands to protect the interests parties with rights. 
Finally, it is important of allowing the concerning parties to participate in the appraisal and supervise the activities. This demand can improve the justice and supervision to these complicated and hard cases to reduce argues. For example, in the famous HUANG Jing's case, if the participants of the related parties can reduce the argument, the appraisals can be greatly minimized, which needs to extend the expert assistant system to the investigation appraisal stage. ${ }^{5}[17]$

\subsubsection{Strengthen the Management of Appraisers}

From these appraisal problems, we can figure out that it's quite urging to improve the abilities of the appraisals and the accuracy of identification. It's a pity that since the publish of "the Decision" in 2005, the relationship of the appraisers and the appraisal organs are parallel management system. On the one hand it registers under the administrative department, and on the other hand it is handled by the court system. [18] It forms the multiple regulations published by the judicial and the Supreme Court, which is called the order coming from several changers.

The publish of "the Decision" in 2005 makes the judicial appraisal have one management by the administrative organ. It cancels the appraisal organs inside the court, develops the social appraisal institution, changes the separated judicial appraisal situation, enforce the appraisers responsibilities system and enhance the appraisers' rate to attend the trials. Until 2012, from 31 province and cities, the appraisal institution charged by the judicial appraisal organs (bureau) increased to 5014. However there are only 18 articles in "the Decision" which is far less than to regulate the appraisal problem scientifically and comprehensively. For example, the obstacles of appraisal and the legal procedures activities do not have consistent regulations, which makes the practice face all kinds of problems and hard to be realized. Some demands are hard to be realized and so far it does not form the complete judicial appraisal management system.

Therefore, the country should launch a revolution of the judicial appraisal management, which includes the management to the investigation organs and the appraisers, and asks the appraisers to fit the lawful conditions and improve their appraisal level and educational training. For example, the government of Shan dong Province has trained more than 2000 staffs to learn video picture processing, microphysical examination, DNA identification, drugs and toxic examination etc. to fulfill the task of criminal law. At the same time they also held a lot of training sessions and taught more than 270 persons the grass-rooted technician to improve their control on the applied system. [19]

5 The No.225 article regulates that $<<$ Italian Criminal Procedure Code $>>$ the public prosecutor and the parties have the rights to appoint their technical consultant; No.230 regulates that they can participate the appraisal work, suggest the detail researching work, publish their opinion and reserve their opinions and should be recorded in the appraisal report. No. 198 article of $<<$ Russia Federal Criminal Procedure Code $>>$ states that in appointed stage and the judicial appraisal, suspect, criminal defendant and their defender have the right to witness the appraisal and explain to the appraisers with the permission of the investigator.

\subsection{The Correction of Judicial Appraisal Procedure}

\subsubsection{Enforcement of the Independence and Justice of the Appraisers}

The revolution appraisal involves many aspects. The overall is to manage the appraisers, standardize the steps and keep the neutrality of the appraisers as stated above.

\subsubsection{The Revolution of the Questioning System in Criminal Proceeding}

The revolution is to make sure that in the future if the previous appraisal exhibits certain defaults, the investigators can still correct it and find the defaults.

Guarantee the appraiser on the trials. No. 187 article of the "Criminal Law" states that When the public prosecutor, the interest party, the defender and the agent as litem hold different opinions with the appraisal opinions, the appraiser should be on the trial. If the appraiser refuses to be on the trail after informed by the court, the appraisal opinions won't be taken. We can see that the different opinions from the interest parties can be the reason for the appraisers to be on trial. However the final decision about whether the appraiser will be no trial or not is decided by the court instead of the interest parties. Meanwhile, the No.198 article of the "Criminal Law" also stated that the court should announce if the opinions will be taken or not on the trial. To some degree, it indicated the arbitrary of the attendance of the appraisers. Because for now China carries out the file-transcript-centrism, many times the judges will announce the appraisal opinions to replace the attendance of the appraisers. What's worse, lacking the compulsory of the related law, the appraisers can choose not to appear on the trial and neglect the relevant duties. In practice, the rate of the appraiser showing up on the trial is quite low, which is less than 5\%. Therefore, the law should take measures to make sure that the necessary appraisers can be questioned by the relevant parties on trials so as to reduce the chance of mistakes that will influence the judgment of the judge.

The expert assistance system should be complete. Because the professional of the appraisal opinions, most of the people lack the judgment to the opinions. In order to prevent the arbitrary and randomness, it is necessary to introduce the experts to assist in the real question. The "Criminal Law" in 2012 stated that the public prosecutor, the relevant parties, the defender and the agent as litem can apply for the assistance of the experts to be on trial and give their opinions. This regulation can help to find out the defaults in the appraisal opinions and evaluate the proving ability of the appraisal opinions to ensure its reliability and the justice of the proceeding procedure.

\subsubsection{Reform the Reappraisal System}

One appraisal can cause the misjudged case therefore there should be the reappraisal system to help the relevant parties. So far there are many questions in the reappraisal system that need further reform.

First of all is to set up the hearing procedure from different parties for the reappraisal. For example, countries 
like Japan carry the typical mainland authority principle, whether to go on the reappraisal procedure should be charged by the court, the procuratorate, and the relevant parties and meanwhile the appraiser should attend. [20] The people who ask for appraisal should state their own reasons and the relevant parties state their views and questions respectively. Finally the court will decide whether reappraise or not by the statement and notes. We can learn from this system that the charging department, the relevant and the appraisers participate in the hearing, debate on the relevant questions to express their dissatisfaction and demand the appraisers to explain the doubts. The holding department can collect the needed information and decide whether there should be the reappraisal. In fact, some procuratorates in province like Shangdong and Fujian have carried out the "Sunshine Appraisal Procedure" for dead cause and injury degree appraisal. The procuratorate invites the relevant parties, the lawyers and the experts to attend the appraisal to make the appraiser accept the appraisal opinions. In the famous HANG Jing's case, if this way was applied, the problems can be solved without costing so much money and efforts, which reduced the judicial public trust.

The second is to reform the reappraisal system. One is to give the relevant parties the right to choose the appraiser and the other is to employ the expert to participate in the appraisal. The time to ask the expert can advance a bit. For the president criminal proceeding regulations, the relevant parties can ask the experts in the trial stage and can also advance the time to set up the file or the proceeding for better settle of the argument in the investigation stage.

\subsection{The Relevant Supporting System}

Also through it should reform the investigation system on scene, improve the criminal technology and standardize, and modify informative it. On the one hand it can effectively extract and preserve materials and on the other hand it can increase the reliability of the judicial appraisal, the investigative ability, protecting human right to avoid the misjudged cases.

\subsubsection{Highlighting the Investigation on Scene and the Extraction and Preservation of the Materials}

The Investigation on scene and the solving result and speed of the case greatly depend on the extraction and preservation of the materials, which asksthe government to increase the investigative founds, consider the investigators as important, guarantee the equipment, use comprehensive criminal investigative method, realize the importance of investigation on scene and increase the efficiency of investigative rate. The investigation stage is the main stage that main evidence remained from the criminal scene. Generally speaking, $60 \%-70 \%$ of evidence which is from the scene in the serious cases is the main resource. [21] So far some investigation organs have made relevant reform and achieved some results. In 2012 the department of criminal science and technology of different levels of the Police in Shandong province have investigated the criminal scene more than 180,000 times, and made more than 230,000 times which were increased by $12.5 \%$ and $9.52 \%$ respectively. Making full use of the investigation on scene and making good preservation of the materials play an important role in solving and accelerating the speed of solving the case, and sometimes it can direct the case. [22]

\subsubsection{Setting up Complete DNA Laboratory and DNA Date System}

The development of the criminal science and technology mainly depend on the advanced labs and experts. For example, the stated criminal misjudged cases mainly occur in central and west areas which is due to that the west regions lack the basic equipment and the top labs to make sure the correctness of the appraisals. For the DNA labs, so far the application of the DNA identification and date basis gradually become the key to solve the case, which is a good equipment to enforce the police force in solving the murder, illegally abduct and traffic women and children, and the serious accident corpse confirmation.

The top labs can make the appraisal more correct and complex material can be tear apart. Meanwhile, setting up a powerful data system benefits the matching and researching process to reduce the cost and increase the efficiency. Taking Shandong province for example, in 2012 it has stored more than 400,000 fingers and the overall storage is more than 6,000,000. More than 20,000 cases were solved in the comparison system in investigation. In 2012, more than 280,000 new DNA data were added into the system and the whole storage reaches more than 1,03,000. The footprints collected from the scene and the suspect are more than 180,000 , and the whole number from the scene broke 500,000 . The police investigation organs solved 8431 chains of criminal cases and then 57,600 cases. They directly solved 3545 chains of criminal cases and 28,100 cases. The above achievement can be attributed to the investment to the technology from the Shandong police. Nearly 10 millions of money were used to build 36 DNA labs and they reconstructed or renewed more than 50 county technical rooms and constructed 7 county police labs with high DNA labs. [23]

Meanwhile, Shanxi province has collected the DNA from the suspects and drug-takers etc.. more than 190,000 and the rate of blood-taking from the relevant people's DNA from the office of hitting the missing people placed in the front line of China that confirmed 43 missing children and moving forward the development of the case.

In the coastal area of Zhejiang province, in the past ten years, the investment to technology is quite huge. During the three years from 1999 to 2002, the province police invested $8,000,000-10,000,000$ yuan annually and 110,7 billions for the criminal technical equipment. In 2008, the automatically fingerprints recognition is realized online in the whole province. All of the criminal technical offices have reached the third standard and 62 of them reached the top standard. $5,540,000$ fingerprints were collected and 15,000 cases can be 
solved by it annually. 3700,000 DNA data were recorded and more than 2060 cases were resolved.

However, so far China does not have a united DNA date base, which are mainly charged inner the police management system. If there could be a nationwide DNA data system the investigation costs can be greatly reduced.

\section{Conclusion}

It is true that this criminal cases together, the criminal identification of the wrong case has played a role in fueling the situation. The reasons for this the imperfect and complicated identification system factors in the context of the last century, the existence of extorting a confession by torture, the qualification of the appraiser and the level of the appraiser. Insufficient, the appraisers have no lack of professional ethics, but also caused by cross-contamination, repeated identification, multi-head identification, and related political factors. However, in the case of a wrong case, the identification system is required to highlight the neutrality, objective and fair attributes, strengthen the protection of criminal suspects' rights, improve related rights relief mechanisms and channels, and strengthen the management of appraisers. The adoption and updating of new technologies in the field of criminal identification can also effectively reduce the occurrence of misjudged cases. Fortunately, after the new century, the number of wrong cases has been greatly reduced. The wrong cases based on criminal identification are rare, and the identification system is reformed and identified. The unified management of personnel has gradually been incorporated into the legislative track, allowing the people to feel fair and justice in every case, and the realization of judicial justice is becoming more visible.

\section{References}

[1] [France] Fene Floriot. Les Eurreurs Judiciaires [M]. ZHAO Shumei, ZHANG Hongzhu. Translation. Beijing: Law Press, 2013:6.

[2] XU Jingcun, the Position of the Appraisal in Criminal Proceedings [J]. Chinese Journal of Forensic Sciences, 2005, (4):3-4.

[3] GUO Hua. The Perspective and Analysis to the Appraisal Institution inner the Investigative Organs--13 Misjudged Cases Concerning the Appraisal Problems $[\mathrm{J}]$ Evidence and Science, 2008, (4):440-451.

[4] NIE Zhaowei. the Reasons and Measures to the Misjudged Cases Concerning Death in the Investigative Stage--Taking the known 33 Misjudged Cases Concerning Death as Samples [J]. Shandong Police College and Journal, 2007, (3):87-92.

[5] Jim petro, Nancy petro, how the injustice happened, translated by yuan ningning, Chen xiao, et al., Beijing: Peking University press, 2012.

[6] Labierejin. The Essay of Criminal Investigation [M]. LI Ruiqin, Translation. Beijing: Masses Publishing House, 1986:69.
[7] CHEN Xuequan. The Analysis of the Application of the DNA in the Criminal Cases [J]. The journal of China criminal law, 2009.4.

[8] HUANG Shiyuan. The Changes and the Reasons of Extortion of Confession by Torture in China in the Recent Years [A]. CHEN Ruihua. Anti-Cruel Torture in the Social Perspective [C]. Beijing:Beijing University Press, 2012:120.

[9] DU Wenhai, ZENG Min. The Analysis and the Prevention of the Problems Causing by the Material Evidence [J]. Chinese Procurator, 2014, (12):36-38.

[10] YI Xiangde. The Correct Understanding of the People's Anger--the Reflection to the Misjudged Cases of DU Peiwu, SHE Xianglin etc. [J]. Modern Law Science, 2006, (1):153-157.

[11] CHEN Wei, SHEN Liqin. The Perspective to American Misjudged Cases and Their Prevention and Enlightenment to Our Justice [J]. Journal of Southwest University of Political Science and Law, 2004, (6):3-12.

[12] Du wenhai and zeng min, "analysis and prevention of wrong cases caused by physical evidence", Chinese prosecutors, 6th issue, 2014

[13] GUAN Meilin, CAO Hui, ZHANG Jianxin. The Source of Stress and the Relevant Factors Exploration of the Police in Beijing, [J]. Chinese Mental Health Journal, 2007, (9):618-621.

[14] DONG Xiujie. The Analysis to the Present Justice to the Criminal Technical Appraisal Value [J] Northeast Agriculture University Journal (Social Version), 2007, (1):110-112.

[15] QU Jiang. The Reasons and the Measures to the Criminal Misjudged Cases Caused by the Wrong Appraisal. [J]. Qinghai Normal University (Philosophy and Social Version), 2012, (5):37-41

[16] CHEN Guangzhong. Criminal Law [M]. Beijing University Press, Tertiary Education Press, 2005:168.

[17] XU Jinghe. the Exploration to the Judicial Appraisal System Revolution [M]. Beijing: Chinese Procurator, 2006:25.

[18] The Effects and the Dissolve of Setting Appraisal Organs inside the Investigative Organs [J]. Modern Law Science, 2009, (6):150-157.

[19] The Explanation of the Decisions of the Management of the Judicial Appraisal of the Bureau of the Criminal Law Attached to the NPC Standing Committee and the NPC [M]. Beijing: Law Science Press, 2005, (6) 6.

[20] LI Na. More than 60,000 Cases Were Solved in Shandong Province Last Year. [N]. People's Police Journal, 2013-02-16 (003).

[21] WU Hejian, LI Yu. Investigation Report of Going to Japan [J]. Chinese Journal of Forensic Sciences, 2002, (4):59-62.

[22] LI Na. Shanxi Province Increases the Investment to Criminal Science [N]. People's Police Journal, 2013-01-17 (005).

[23] ZHOU Zhitao, YOU Weixiang. Outstanding Because of Professional--the Review and the Theoretical Explanation to the Past Ten Years Criminal Work in Zhejiang Province. [J] Zhengjiang Police College Journal, 2009, (2):59-63 


\section{Biography}

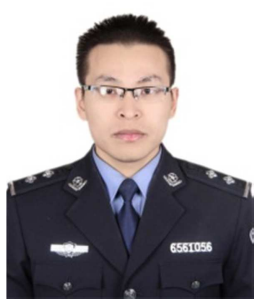

Lang Zhicheng: From jiangxi province. China (1991.05--). The research direction: Evidence system ; Border governance, now stay in College Of Xinjiang Corps Police 